\title{
Comparison of growth performance and slaughter characteristics of Limousin and Charolais heifers
}

\author{
RADKA ZAHRÁDKOVÁ, LUDĚK BARTOŇ, DANIEL BUREŠ, VÁCLAV TESLÍK and VÁCLAV \\ KUDRNA
}

Institute of Animal Science, Prague - Uhříněves, Czech Republic

\begin{abstract}
The objective of this study was to determine the effects of breed and a diet containing linseed on the growth and carcass composition characteristics of heifers. A total of 48 Limousin (LI) and Charolais (CH) heifers with an average weight of $270 \mathrm{~kg}$ were assigned to two diets containing either extruded linseed (LIN) or no supplemental oilseed (CON). The target slaughter weight was set at $500 \mathrm{~kg}$. The diet had no effect on any of the observed production traits. The $\mathrm{CH}$ heifers had higher live weight gains $(P<0.001)$ and a lower feed conversion ratio $(P<0.001)$. The $\mathrm{LI}$ heifers had a higher dressing percentage $(P<0.001)$, higher meat to bone ratio $(P<0.001)$, greater $m$. longissimus lumborum et thoracis area $(P<0.05)$, and produced more internal and carcass fat $(P<0.05)$. It was concluded that purebred $\mathrm{LI}$ heifers grew less rapidly and less efficiently but produced heavier carcasses with a more favourable meat to bone ratio compared to purebred $\mathrm{CH}$ heifers.
\end{abstract}

Keywords: heifers, Charolais, Limousin, linseed, growth, carcass composition

\section{Zusammenfassung}

\section{Vergleich von Wachstums- und Schlachtkörpermerkmalen bei Färsen der Rassen Limousin und Charolais}

Verglichen wurden Wachstums- und Schlachtkörpermerkmale bei Färsen der Rassen Limousin (LI) und Charolais (CH), die mit oder ohne gepressten Leinsamen gefüttert wurden. Einbezogen waren 48 Färsen beider Rasse bei einem Versuchsbeginn mit durchschnittlich $270 \mathrm{~kg}$ bis zur Schlachtung von durchschnittlich $500 \mathrm{~kg}$. Ein Fütterungseinfluss bei Leinsamenzugaben konnte nicht nachgewiesen werden. $\mathrm{CH}$-Färsen erreichten gegenüber LI-Färsen signifikant höhere tägliche Zunahmen bei geringerem Nährstoffbedarf je kg Lebendgewichtszuwachs. LI-Färsen zeigten ein signifikant geringeres Wachstum, höhere Schlachtausbeuten, ein günstigeres Fleisch : Knochenverhältnis, größere Flächen beim $m$. longissimus lumborum und $m$. thoracis, einen höheren Innenfettanteil und Verfettungsgrad der Schlachtkörper.

Schlüsselwörter: Färse, Charolais, Limousin, Leinsamen, Wachstum, Schlachtkörperzusammensetzung 


\section{Introduction}

In contrast to dairy and dual-purpose cattle, the stock of beef animals, including crossbreds, has been increasing in the Czech Republic over the last fifteen years. At present, there are a total of 12 beef breeds widely differing in their production characteristics. Of them, the French breeds Limousin and Charolais belong to the most numerous beef breeds, representing 9 and $25 \%$, respectively, of the total number of suckler cows. Female calves that are not used for herd replacement are either sold or fattened and provide a valuable source of high quality meat.

Growth ability and meat performance are of great economic importance in beef cattle. Many authors were concerned with genetic evaluation of growth ability in beef breeds (JAKUBEC et al. 2003, SZABÓ et al. 2007, VOSTRÝ et al. 2007). Large variations in growth performance and carcass composition traits exist among different beef breeds (HOLLÓ et al. 2004, BARTOŇ et al. 2006, CUVELIER et al. 2006, LINK et al. 2007, ALBERTí et al. 2008). Therefore, breed comparison experiments provide valuable information on the suitability of different beef breeds for different production and market conditions.

The differences in production traits between Charolais and Limousin breeds have been previously studied in bulls (JURIE et al. 2005), cows (JURIE et al. 2006), and steers (MANDELL et al. 1997, CHAMBAZ et al. 2001). Only limited information is, however, available about the fattening capacity and carcass value of young heifers of these breeds.

It is well known that diets supplemented with linseed improve the fatty acid profile of beef, lamb and pork from the human health perspective (HOLLÓ et al. 2005, GRUSZECKI et al. 2006, SCOLLAN et al. 2006, VÁCLAVKOVÁ and BEČKOVÁ, 2007). However, the effects of different dietary treatments involving linseed on production traits of fattened cattle are not entirely clear and need to be elucidated. Therefore, the objective of the present study was to determine the effects of breed and a diet containing linseed on the growth and carcass composition characteristics of heifers.

\section{Material and methods}

The experiment involved 24 Limousin (LI) and 24 Charolais $(\mathrm{CH})$ purebred heifers. The animals were purchased from two commercial farms after weaning at the age of approx. 8 months. The heifers were loose-housed in pens with straw bedding, and during a 2-month adaptation period they were given a mixed diet consisting of maize silage, grass hay, and concentrates (wheat and extruded soybean meal). At the beginning of the experimental period, the animals of each breed were assigned according to live weight and age to one of two diets containing either extruded linseed (LIN) or no supplemental oilseed (CON). Both diets offered ad libitum were isocaloric and isonitrogenous but differed in the content and source of dietary fat. Diet ingredient samples were regularly collected and analysed. The feeds were dried at $105^{\circ} \mathrm{C}$ to a constant weight. Crude protein, fat, and fibre contents were determined using the Kjeltec AUTO 1030 Analyser, Soxtec 1043 and Fibertec 2010 (FOSS Tecator AB, Höganäs, Sweden) instruments, respectively. The average ingredient and chemical composition of the diets has been reported previously (BARTOŇ et al. 2007a).

The heifers were fed from electronically controlled feeding troughs (Insentec, Marknesse, The Netherlands), and thus the individual daily feed intake of each heifer could be recorded. 
The animals were weighed at the beginning of the experiment and then every two weeks. The target live weight was $500 \mathrm{~kg}$. Two animals from the CON group (1 LI and $1 \mathrm{CH}$ ) had to be withdrawn from the experiment due to health problems. The growth and feed intake data were separately analysed for the period from the start to day 168 of the experiment (when the first heifers reached the target live weight and were slaughtered) and for the entire experiment from start to slaughter. The two or three heaviest animals from each dietary regime were selected for slaughter on each slaughter day. These animals were weighed 3 days before slaughter (final weight used for the calculation of daily live weight gain and feed intake) and on the slaughter day after approximately $18 \mathrm{~h}$ of fasting (slaughter weight used for the calculation of slaughter characteristics).

The slaughtering was performed in the experimental abattoir of the Institute of Animal Science. The heifers were stunned with a captive bolt gun and killed by exsanguination. The carcasses were dressed according to EU specifications and assessed by a trained classifier for conformation (a 6-point scale) and external fatness (a 5-point scale) according to the SEUROP classification system (EU 2008). The weights of the hot carcass and internal fat depots (kidney, rumen, and udder fat) were recorded. The dressing percentage was calculated as $100 \times$ hot carcass weight/slaughter weight. Carcass gain was obtained as the ratio of hot carcass weight to days of age at slaughter.

After chilling for approximately $24 \mathrm{~h}$, cold carcass weights were recorded and the right sides were divided into standardized joints. The joints were separated into lean meat, bones and tendons, and separable fat (subcutaneous and intermuscular), and their weights were recorded. The total meat yield was calculated as the lean meat from all joints plus the lean trimmings. High-priced meat was determined as the total weight of lean meat from the trimmed rump, shoulder, loin and fillet, and low-priced meat as the lean meat from the remaining joints plus the lean trimmings. The $m$. longissimus lumborum et thoracis (MLLT) area was measured planimetrically at the section between the 8th and 9th thoracic vertebrae.

The GLM procedure of SAS (SAS 2001) was used to analyse all experimental data. Fixed effects of breed and diet and their interaction were included in the initial model. However, the interactions were omitted from the final model, as they were not significant for any of the examined traits. In addition, the age at the beginning of the experiment (overall mean 293 days) was used as a covariate for growth performance traits and carcass gain, while the slaughter weight (overall mean $489 \mathrm{~kg}$ ) was used as a covariate for slaughter and carcass composition traits. Thus, the following statistical model was used:

$$
y_{i j k l}=\mu+A_{i}+B_{j}+\beta x_{i j k l}+e_{i j k l}
$$

Where $y_{i j k l}$ is the analysed trait, $\mu$ is the mean value, $A_{i}$ is the effect of breed, $B_{j}$ is the effect of diet, $\beta$ is the regression coefficient, $x_{i j k l}$ is the alternatively initial age or slaughter weight and $e_{i j k l}$ is the residual error.

Main effects (breed and diet) least-squares means, their standard errors, and levels of significance are presented in the tables. 


\section{Results and Discussion}

\section{Effects of diet}

Linseed was included in the diet to primarily examine its potential for improving the fatty acid profile of beef, and the results have been published elsewhere (BARTOŇ et al. 2007a). The aim of the present study was to determine the effect of linseed feeding on production traits of fattened cattle. However, no significant effects of linseed feeding (approx. $7 \%$ of extruded linseed on a DM basis) on growth, slaughter, and carcass traits were detected (Tables 1, 2 and 3). The inclusion of differentially processed linseed increased the average daily gain and gain to feed ratio in beef heifers probably due to the higher energy density of the linseed diets (MADDOCK et al. 2006). However, when the consumed diets were similar in their energy and protein content, linseed feeding did not significantly influence most of the growth and carcass traits (RAZMINOWICZ et al. 2008), which is in accordance with the present results. In a study by HOLLÓ et al. (2008) the diet with linseed supplementation caused significantly lower daily gain, but it had no effect on slaughtering and dressing traits in fattening bulls. It is apparent that the inclusion of extruded linseed in the diet at a reasonable level has no deteriorating effect on the production characteristics of beef heifers.

\section{Effect of breed}

The data of growth performance adjusted for a common age at the beginning of the experiment are given in Table 1. The animals of both groups were similar in their initial live weight. At day 168 , however, the $\mathrm{CH}$ animals were heavier by $31 \mathrm{~kg}(P<0.05)$ as a result of a significantly higher daily live weight gain $(P<0.001)$ during this period. Similarly, the $\mathrm{CH}$ heifers grew more rapidly throughout the entire experimental period by $250 \mathrm{~g}$ on the average $(P<0.001)$ and consequently reached the final weight $45 \mathrm{~d}$ earlier $(P<0.001)$ compared to the $\mathrm{LI}$ animals. Among the beef breeds, $\mathrm{CH}$ is well-known for its excellent growth performance (BARTOŇ et al. 2007b). Higher live weight gains of $\mathrm{CH}$ compared to $\mathrm{LI}$ animals were reported in a number of previous studies (e.g. MANDELL et al. 1997). Furthermore, similar results were also observed in the comparison of $\mathrm{CH}$ - and LI-sired crosses (FRELICH et al. 1998). In contrast, no significant differences in average daily gains between $\mathrm{CH}$ and $\mathrm{LI}$ bulls were found in a study investigating the variation in production traits of 15 European cattle breeds (ALBERTÍ et al. 2008).

No significant breed differences were observed in feed (dry matter, protein digested in the small intestine, net energy of fattening, and crude fibre) intake in both analysed experimental periods, which is in agreement with the results of MANDEL et al. (1997), who compared LI and $\mathrm{CH}$ steers at two slaughter endpoints. Contrary to the present results, however, lower feed intake capacity of $\mathrm{LI}$ compared to $\mathrm{CH}$ steers was reported (CHAMBAZ et al. 2001), possibly due to a lower digestive tract weight of the LI. AKBAS et al. (2006) explained the lower feed intake capacity of Limousin and Piemontese crossbred bulls as a result of their doublemuscle characterization. Due to markedly higher live weight gains, the $\mathrm{CH}$ heifers exhibited a lower feed conversion ratio (daily nutrient intake/daily live weight gain) than the LI animals $(P<0.001)$ in the first experimental period and during the entire experiment. An improved feed conversion ratio was also found in Charolais compared to Holstein bulls due to a higher growth capacity in $\mathrm{CH}$ animals in a study by PFUHL et al. (2007). 
Table 1

Growth performance

Wachstumsmerkmale

\begin{tabular}{lcccccccccc}
\hline & \multicolumn{4}{c}{ Breed } & \multicolumn{3}{c}{ Diet } & \multicolumn{3}{c}{ Significance } \\
& \multicolumn{2}{c}{ LI $(\mathrm{n}=23)$} & \multicolumn{2}{c}{ CH $(\mathrm{n}=23)$} & LIN $(\mathrm{n}=24)$ & \multicolumn{2}{c}{ CON $(\mathrm{n}=22)$} & & \\
& LSM & SEM & LSM & SEM & LSM & SEM & LSM & SEM & Breed & Diet \\
\hline Initial weight, $\mathrm{kg}$ & 278.1 & 7.4 & 261.7 & 7.4 & 269.0 & 6.5 & 270.9 & 6.8 & 0.154 & 0.845 \\
Weight at d 168, kg & 431.2 & 9.2 & 462.3 & 9.2 & 443.9 & 8.2 & 449.6 & 8.5 & 0.033 & 0.631 \\
Final weight, kg & 505.5 & 6.4 & 507.3 & 6.4 & 503.4 & 5.6 & 509.3 & 5.9 & 0.852 & 0.474 \\
Final age, d & 562.2 & 4.9 & 517.0 & 4.9 & 540.4 & 4.3 & 538.7 & 4.5 & $<0.001$ & 0.786 \\
Duration & 269.2 & 4.9 & 224.0 & 4.9 & 247.5 & 4.3 & 245.7 & 4.5 & $<0.001$ & 0.780
\end{tabular}

Period from start to 168 of the experiment

\begin{tabular}{|c|c|c|c|c|c|c|c|c|c|c|}
\hline $\begin{array}{l}\text { Live weight gain, } \mathrm{kg} / \mathrm{d} \\
\text { Feed intake }\end{array}$ & 0.911 & 0.025 & 1.194 & 0.025 & 1.041 & 0.022 & 1.064 & 0.023 & $<0.001$ & 0.477 \\
\hline Dry matter, $\mathrm{kg} / \mathrm{d}$ & 6.39 & 0.17 & 6.71 & 0.17 & 6.45 & 0.15 & 6.65 & 0.16 & 0.244 & 0.388 \\
\hline $\mathrm{PDIN}, \mathrm{kg} / \mathrm{d}^{\mathrm{a}}$ & 0.46 & 0.01 & 0.49 & 0.01 & 0.46 & 0.01 & 0.49 & 0.01 & 0.242 & 0.133 \\
\hline$N E F, M J / d^{b}$ & 40.8 & 1.1 & 42.8 & 1.1 & 41.2 & 1.0 & 42.4 & 1.0 & 0.244 & 0.429 \\
\hline Crude fibre, $\mathrm{kg} / \mathrm{d}$ & 1.22 & 0.03 & 1.28 & 0.03 & 1.22 & 0.03 & 1.27 & 0.03 & 0.246 & 0.223 \\
\hline \multicolumn{11}{|l|}{ Feed conversion ratio } \\
\hline Dry matter, $\mathrm{kg} / \mathrm{kg}$ gain & 7.01 & 0.14 & 5.60 & 0.14 & 6.29 & 0.12 & 6.32 & 0.13 & $<0.001$ & 0.857 \\
\hline PDIN, kg/kg gain a & 0.51 & 0.01 & 0.41 & 0.01 & 0.45 & 0.01 & 0.46 & 0.01 & $<0.001$ & 0.327 \\
\hline $\mathrm{NEF}, \mathrm{MJ} / \mathrm{kg}$ gain $^{\mathrm{b}}$ & 44.7 & 0.9 & 35.8 & 0.9 & 40.2 & 0.8 & 4.03 & 0.8 & $<0.001$ & 0.928 \\
\hline Crude fibre, $\mathrm{kg} / \mathrm{kg}$ gain & 1.33 & 0.03 & 1.07 & 0.03 & 1.19 & 0.02 & 1.21 & 0.02 & $<0.001$ & 0.534 \\
\hline \multicolumn{11}{|c|}{ Period from start to end of the experiment } \\
\hline $\begin{array}{l}\text { Live weight gain, } \mathrm{kg} / \mathrm{d} \\
\text { Feed intake }\end{array}$ & 0.850 & 0.025 & 1.104 & 0.025 & 0.964 & 0.023 & 0.991 & 0.024 & $<0.001$ & 0.418 \\
\hline Dry matter, $\mathrm{kg} / \mathrm{d}$ & 6.52 & 0.16 & 6.85 & 0.16 & 6.59 & 0.14 & 6.77 & 0.15 & 0.185 & 0.373 \\
\hline PDIN, kg/da & 0.47 & 0.01 & 0.50 & 0.01 & 0.47 & 0.01 & 0.50 & 0.01 & 0.185 & 0.105 \\
\hline $\mathrm{NEF}, \mathrm{MJ} / \mathrm{d}^{\mathrm{b}}$ & 41.6 & 1.0 & 43.7 & 1.0 & 42.1 & 0.9 & 43.2 & 0.9 & 0.184 & 0.417 \\
\hline Crude fibre, $\mathrm{kg} / \mathrm{d}$ & 1.24 & 0.03 & 1.30 & 0.03 & 1.25 & 0.03 & 1.30 & 0.03 & 0.185 & 0.195 \\
\hline \multicolumn{11}{|l|}{ Feed conversion ratio } \\
\hline Dry matter, $\mathrm{kg} / \mathrm{kg}$ gain & 7.69 & 0.35 & 6.21 & 7.69 & 6.93 & 0.15 & 6.97 & 0.15 & $<0.001$ & 0.856 \\
\hline PDIN, kg/kg gain a & 0.56 & 0.16 & 0.45 & 0.56 & 0.50 & 0.01 & 0.51 & 0.01 & $<0.001$ & 0.355 \\
\hline $\mathrm{NEF}, \mathrm{MJ} / \mathrm{kg}$ gain $^{\mathrm{b}}$ & 49.1 & 1.1 & 39.66 & 49.1 & 44.3 & 0.9 & 44.4 & 1.0 & $<0.001$ & 0.919 \\
\hline Crude fibre, $\mathrm{kg} / \mathrm{kg}$ gain & 1.46 & 0.03 & 1.18 & 1.46 & 1.31 & 0.03 & 1.34 & 0.03 & $<0.001$ & 0.551 \\
\hline
\end{tabular}

aProtein digested in the small intestine supplied by rumen-undegraded protein and microbial protein from rumen-

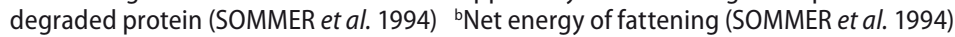

Thus, at approximately the same body weight range, the $\mathrm{CH}$ heifers gained more efficiently than LI. Among other factors, the differences in feed efficiency can be explained by a different composition of body weight gain, as the deposition of lipids requires a higher feed energy intake compared to protein (HERD et al. 2004). In the present study, the lower feed conversion ratio of the $\mathrm{LI}$ heifers may be due to their higher production of internal and carcass fat as further discussed below.

The development of body weight and dry matter intake from start to day 168 of the experiment, when the first animals were slaughtered, is shown in Figure 1. While the growth of heifers was generally linear in this period, the dry matter intake increased only until approximately day 70 of the experiment (about 360 days of age), and then remained stable. 
In the final period of the experiment (from day 168 on), daily gains were reduced, and the feed conversion ratio increased in both breed groups. This pattern of growth and feed intake development was widely in agreement with the results of a fattening experiment with steers of different beef breeds (CHAMBAZ et al. 2001).

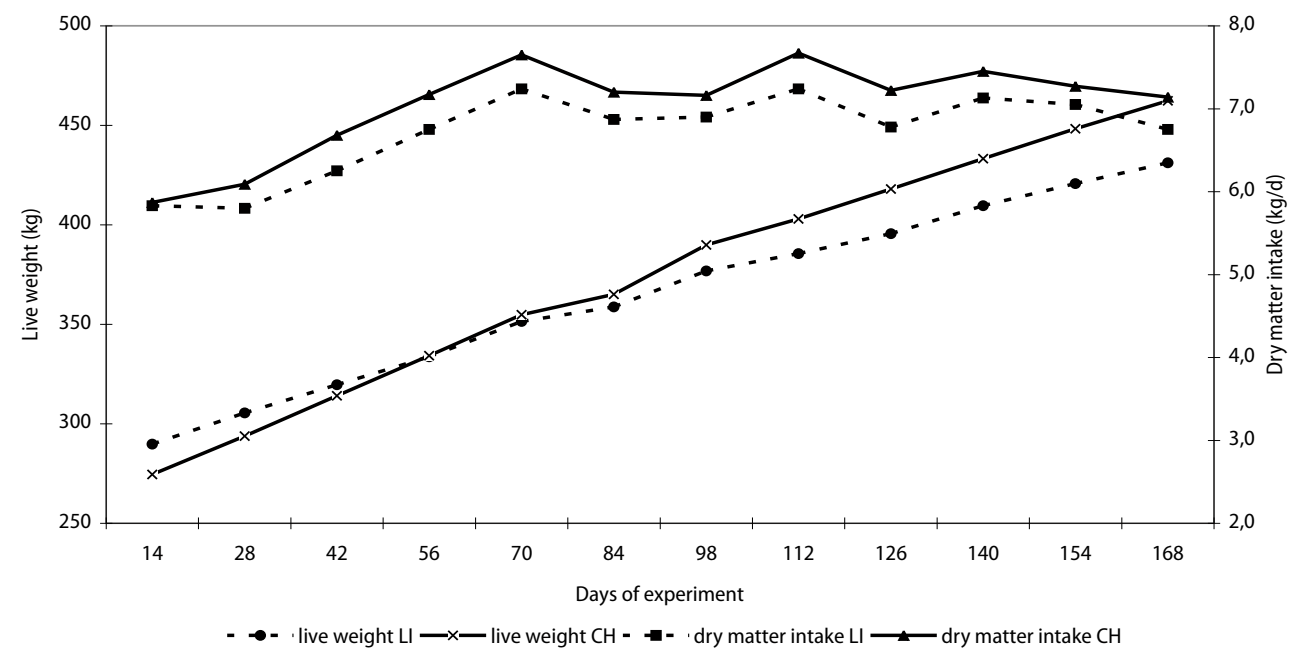

Figure 1

Live weight and dry matter intake from start to day 168

Lebendgewicht und Trockenmasseaufnahme vom 14. bis 168. Tag

Slaughter characteristics are summarized in Table 2. When adjusted for common slaughter weight, the $\mathrm{LI}$ heifers produced heavier carcasses $(P<0.001)$ and had a higher dressing percentage $(P<0.001)$. They also received higher fatness scores $(P<0.001)$, whereas conformation scores were similar in both groups. In addition, the LI deposited more kidney $(P<0.05)$, rumen $(P<0.05)$, and udder $(P<0.01)$ fat. The superiority of $\mathrm{LI}$ compared to most beef breeds in dressing percentage has been previously well documented in experiments with crossbred as well as purebred animals (WHEELER et al. 2005, ALBERTÍ et al. 2008).

On the other hand, the higher degree of fatness of the $\mathrm{LI}$ heifers compared to $\mathrm{CH}$ is rather surprising, as in other studies no differences between these breeds in fatness scores and fat production were reported, or the fatness exhibited by LI was even lower (MANDELL et al. 1997, ALBERTÍ et al. 2008). The explanation of the observed results may be related to the different physiological age of the animals used in our experiment and/or the prolonged fattening period of the LI group. The compared breeds differed in a number of carcass composition traits (Table 3). At a common slaughter weight, the $\mathrm{LI}$ heifers produced heavier right carcass sides $(P<0.001)$, more total $(P<0.001)$, high-priced $(P<0.01)$, and low-priced $(P<0.001)$ meat, more fat separated during dissections $(P<0.01)$, and less bone and tendon $(P<0.001)$. When expressed as percentages of the right side weight, the LI tended towards a higher proportion of total meat $(P=0.092)$, they had a lower percentage of bones and tendons $(P<0.001)$, and a higher percentage of separable fat $(P<0.05)$. 
Table 2

Slaughter characteristics

Schlachtmerkmale

\begin{tabular}{|c|c|c|c|c|c|c|c|c|c|c|}
\hline & \multicolumn{4}{|c|}{ Breed } & \multicolumn{4}{|c|}{ Diet } & \multicolumn{2}{|c|}{ Significance } \\
\hline & \multicolumn{2}{|c|}{$\mathrm{LI}(\mathrm{n}=23)$} & \multicolumn{2}{|c|}{$\mathrm{CH}(\mathrm{n}=23)$} & \multicolumn{2}{|c|}{ LIN $(n=24)$} & \multicolumn{2}{|c|}{$\operatorname{CON}(n=22)$} & \multirow[b]{2}{*}{ Breed } & \multirow[b]{2}{*}{ Diet } \\
\hline & LSM & SEM & LSM & SEM & LSM & SEM & LSM & SEM & & \\
\hline Carcass weight, kg & 296.3 & 2.22 & 281.8 & 2.2 & 288.8 & 2.1 & 289.2 & 2.2 & $<0.001$ & 0.893 \\
\hline Dressing percentage, $\%$ & 60.6 & 0.4 & 57.7 & 0.4 & 59.1 & 0.4 & 59.1 & 0.4 & $<0.001$ & 0.955 \\
\hline Carcass gain, $\mathrm{kg} / \mathrm{d}$ & 0.518 & 0.011 & 0.543 & 0.011 & 0.529 & 0.006 & 0.531 & 0.007 & 0.141 & 0.801 \\
\hline Conformation ${ }^{\mathrm{a}}$ & 3.42 & 0.11 & 3.54 & 0.11 & 3.44 & 0.11 & 3.52 & 0.11 & 0.430 & 0.621 \\
\hline Fatness $^{\mathrm{b}}$ & 3.30 & 0.11 & 2.87 & 0.11 & 3.18 & 0.11 & 2.99 & 0.11 & 0.010 & 0.223 \\
\hline Kidney fat, $\%^{c}$ & 2.31 & 0.10 & 1.55 & 0.10 & 1.93 & 0.09 & 1.93 & 0.10 & $<0.001$ & 0.968 \\
\hline Rumen fat, $\%$ c & 1.07 & 0.09 & 0.77 & 0.09 & 0.93 & 0.09 & 0.90 & 0.09 & 0.030 & 0.854 \\
\hline Udder fat, $\%^{c}$ & 1.10 & 0.05 & 0.87 & 0.05 & 0.98 & 0.04 & 0.99 & 0.05 & 0.001 & 0.908 \\
\hline
\end{tabular}

${ }^{\mathrm{a}}$ scale $1 \mathrm{~S}$ (best) to $6 \mathrm{P}$ (poorest), ${ }^{\mathrm{b}}$ scale 1 (leanest) to 5 (fattest), c\% of slaughter weight

They also exhibited a higher meat: bones and tendons ratio $(P<0.001)$ and a greater MLLT area/100 $\mathrm{kg}$ of slaughter weight $(P<0.05)$. The capacity of the $\mathrm{LI}$ breed to produce carcasses with high lean meat yields has been reported in a number of previous studies (MANDELL et al. 1997, WHEELER et al. 2005, ALBERTí et al. 2008). A favourably high meat to bones and tendons ratio in the $\mathrm{LI}$ was also confirmed in a study by CHAMBAZ et al. (2001).

Table 3

Carcass composition

Zusammensetzung des Schlachtkörpers

\begin{tabular}{|c|c|c|c|c|c|c|c|c|c|c|}
\hline & \multicolumn{4}{|c|}{ Breed } & \multicolumn{4}{|c|}{ Diet } & \multicolumn{2}{|c|}{ Significance } \\
\hline & \multicolumn{2}{|c|}{ LI $(n=23)$} & \multicolumn{2}{|c|}{$\mathrm{CH}(\mathrm{n}=23)$} & \multicolumn{2}{|c|}{ LIN (n=24) } & \multicolumn{2}{|c|}{$\operatorname{CON}(n=22)$} & \multirow[b]{2}{*}{ Breed } & \multirow[b]{2}{*}{ Diet } \\
\hline & LSM & SEM & LSM & SEM & LSM & SEM & LSM & SEM & & \\
\hline Right side, kg & 145.3 & 1.1 & 138.3 & 1.1 & 141.6 & 1.1 & 142.1 & 1.1 & $<0.001$ & 0.735 \\
\hline Total meat, kg & 113.9 & 1.2 & 107.1 & 1.2 & 110.2 & 1.1 & 110.7 & 1.2 & $<0.001$ & 0.740 \\
\hline Total meat, \% ${ }^{\mathrm{a}}$ & 78.3 & 0.4 & 77.4 & 0.4 & 77.8 & 0.3 & 77.9 & 0.4 & 0.092 & 0.856 \\
\hline Bones, kg & 24.1 & 0.3 & 25.5 & 0.3 & 25.0 & 0.2 & 24.7 & 0.2 & $<0.001$ & 0.338 \\
\hline Bones, $\%$ a & 16.6 & 0.2 & 18.5 & 0.2 & 17.7 & 0.2 & 17.4 & 0.2 & $<0.001$ & 0.354 \\
\hline High-priced meat, kg & 59.9 & 0.8 & 56.1 & 0.8 & 58.1 & 0.8 & 57.9 & 0.8 & 0.002 & 0.879 \\
\hline High-priced meat, \%a & 41.2 & 0.4 & 40.6 & 0.4 & 41.0 & 0.3 & 40.7 & 0.4 & 0.250 & 0.551 \\
\hline Low-priced meat, kg & 53.9 & 0.5 & 51.0 & 0.5 & 52.1 & 0.5 & 52.8 & 0.5 & $<0.001$ & 0.337 \\
\hline Low-priced meat, \%a & 37.1 & 0.2 & 36.8 & 0.2 & 36.8 & 0.2 & 37.2 & 0.2 & 0.335 & 0.180 \\
\hline High/low priced meat & 1.11 & 0.01 & 1.10 & 0.01 & 1.11 & 0.01 & 1.10 & 0.01 & 0.652 & 0.270 \\
\hline Total meat/bones & 4.72 & 0.06 & 4.20 & 0.06 & 4.43 & 0.06 & 4.49 & 0.06 & $<0.001$ & 0.463 \\
\hline \multicolumn{11}{|l|}{ MLLT area/100 kg } \\
\hline slaughter weight, $\mathrm{cm}^{2}$ & 16.5 & 0.5 & 14.8 & 0.5 & 15.5 & 0.5 & 15.8 & 0.5 & 0.017 & 0.665 \\
\hline Separable fat, $\mathrm{kg}$ & 7.35 & 0.41 & 5.70 & 0.41 & 6.37 & 0.39 & 6.67 & 0.41 & 0.008 & 0.602 \\
\hline Separable fat, $\%^{a}$ & 5.08 & 0.29 & 4.12 & 0.29 & 4.51 & 0.28 & 4.69 & 0.29 & 0.029 & 0.661 \\
\hline
\end{tabular}

a $\%$ of right side weight

It is concluded that the $\mathrm{CH}$ heifers outperformed the $\mathrm{LI}$ animals in terms of daily live weight gain and feed conversion ratio in both analysed experimental periods. They also had 
lower proportions of carcass and internal fat. In contrast, the LI heifers produced heavier carcasses with a higher meat to bone ratio. The inclusion of extruded linseed at the level of approximately $7 \%$ on a DM basis had no effect on any of the observed production traits.

\section{Acknowledgements}

Supported by the Ministry of Agriculture of the Czech Republic (Project MZe 0002701404).

\section{References}

Akbas Y, Alcicek A, Önenc A, Güngör M (2006) Growth curve analysis for body weight and dry matter intake in Friesian, Limousin x Friesian and Piemontese x Friesian cattle. Arch Tierz 49, 329-39

Albertí P, Panea B, Sanudo C, Olleta JL, Ripoll G, Ertbjerg P, Christensen M, Gigli S, Failla S, Concetti S, Hocquette JF, Jailler R, Rudel S, Renand G, Nute GR, Richardson RI, Williams JL (2008) Live weight, body size and carcass characteristics of young bulls of fifteen European breeds. Livest Sci 114, 19-30

Bartoň L, Řehák D, Teslík V, Bureš D, Zahrádková R (2006) Effect of breed on growth performance and carcass composition of Aberdeen Angus, Charolais, Hereford and Simmental bulls. Czech J Anim Sci 51, 47-53

Bartoň L, Marounek M, Kudrna V, Bureš D, Zahrádková R (2007a) Growth performance and fatty acid profiles of intramuscular and subcutaneous fat from Limousin and Charolais heifers fed extruded linseed. Meat Sci $76,517-23$

Bartoň L, Kudrna V, Bureš D, Zahrádková R, Teslík V (2007b) Performance and carcass quality of Czech Fleckvieh, Charolais and Charolais $x$ Czech Fleckvieh bulls fed diets based on different types of silages. Czech J Anim Sci 52, 269-76

Chambaz A, Morel I, Scheeder MRL, Kreuzer M, Dufey PA (2001) Characteristics of steers of six beef breeds fattened from eight months of age and slaughtered at a target level of intramuscular fat I. Growth performance and carcass quality. Arch Tierz 44, 395-411

Cuvelier C, Cabaraux JF, Dufrasne I, Clinquart A, Hocquette JF, Istasse L, Hornick JL (2006) Performance, slaughter characteristics and meat quality of young bulls from Belgian Blue, Limousin and Aberdeen Angus breeds fattened with a sugar-beet pulp or a cereal-based diet. Anim Sci 82, 125-32

EU (2008) Commission Regulation (EC) No. 1249/2008 laying down detailed rules on the implementation of the Community scales for the classification of beef, pig and sheep carcases and the reporting of prices thereof. Off J Eur Union 337, 3-26

Frelich J, Voříšková J, Kuník J, Kvapilík J (1998) Fattening ability and carcass value of bulls - crossbreds of Bohemian Spotted cattle with beef breeds. Arch Tierz 41, 533-44

Gruszecki T, Junkuszew A, Lipiek A, Lipecka C, Szymanowska A, Patkowski K, Szymanowski M (2006) Composition of fatty acid of muscle tissue of lambs fed feedstuff supplemented with flax seeds. Arch Tierz 49 Special Issue, $181-5$

Herd RM, Oddy VH, Richardson EC (2004) Biological basis for variation in residual feed intake in beef cattle. 1. Review of potential mechanisms. Aust J Exp Agric 44, 423-30

Holló G, Nürnberg K, Seregi J, Hollo I, Repa I, Ender K (2004) Influence of feeding on fatteneing performance and carcass quality of young Hungarian Grey and Holstein Friesian bulls. Arch Tierz 47, 313-23 [in German]

Holló G, Nürnberg K, Repa I, Hollo I, Seregi J, Pohn G, Ender K (2005) Effect of feeding on the composition of the intramuscular fat in longissimus muscle and different fatty tissues of Hungarian Grey and Holstein Friesian bulls. 1. Fatty acid profile. Arch Tierz 48, 537-46 [in German]

Holló G, Ender K, Lóki K, Seregi J, Holló I, Nürnberg K (2008) Carcass characteristics and meat quality of Hungarian Simmental young bulls fed different forage to concentrate ratios with or without linseed supplementation. Arch Tierz 51, 517-30

Jakubec V, Schlote W, Říha J, Majzlík I (2003) Comparison of growth traits of eight beef cattle breeds in the Czech Republic. Arch Tierz 46, 143-53 
Jurie C, Martin JF, Listrat A, Jailler R, Culioli J, Picard B (2005) Effects of age and breed of beef bulls on growth parameters, carcass and muscle characteristics. Anim Sci 80, 257-63

Jurie C, Martin JF, Listrat A, Jailler R, Culioli J, Picard B (2006) Carcass and muscle characteristics of beef cull cows between 4 and 9 years of age. Anim Sci 82, 415-21

Link G, Willeke H, Golze M, Bergfeld U (2007) Fattening-and slaughter performance of bulls and heifers of beef breeds and the cross breed German Angus x Simmental. Arch Tierz 50, 356-62 [in German]

Maddock TD, Bauer ML, Koch KB, Anderson VL, Maddock RJ, Barcelo-Coblijn G, Murphy EJ, Lardy GP (2006) Effect of processing flax in beef feedlot diets on performance, carcass characteristics, and trained sensory panel ratings. J Anim Sci 84, 1544-51

Mandell IB, Gullett EA, Wilton JW, Allen OB, Osborne VR (1997) Effects of diet, breed and slaughter endpoint on growth performance, carcass composition and beef quality traits in Limousin and Charolais steers. Can J Anim Sci 77, 23-32

Pfuhl R, Bellmann O, Kühn Ch, Teuscher F, Ender K, Wegner J (2007) Beef versus dairy cattle: a comparison of feed conversion, carcass composition, and meat quality. Arch Tierz 50, 59-70

Razminowicz RH, Kreuzer M, Leuenberger H, Scheeder MRL (2008) Efficiency of extruded linseed for the finishing of grass-fed steers to counteract a decline of omega-3 fatty acids in the beef. Livest Sci 114, 150-63

SAS Institute Inc (2001) Release 8.2 (TS2MO) of the SAS ${ }^{\circledR}$ System for Microsoft ${ }^{\oplus}$ Windows ${ }^{\circledR}$. SAS Institute Inc Cary NC USA

Scollan N, Hocquette JF, Nuernberg K, Dannenberger D, Richardson IMA (2006) Innovations in beef production systems that enhance the nutritional and health value of beef lipids and their relationship with meat quality. Meat Sci 74, 17-33

Sommer A, Čerešňáková Z, Frydrych Z, Králík O, Králíková Z et al. (1994) Nutrient requirements and nutritive values of feeds for ruminants. ČAZV, Pohořelice, Che [in Czech]

Szabó F, Lengyel Z, Domokos Z, Bene S (2007) Estimation of genetic parameters and (co)variance components for weaning traits of Charolais population in Hungary. Arch Tierz 50, 447-54

Váckavková E, Bečková R (2007) Effect of linseed in pig diet on meat quality and fatty acid content. Arch Tierz 50 Special Issue, $144-51$

Vostrý L, Pribyl J, Veselá Z, Jakubec V (2007) Selection of a suitable data set and model for the estimation of genetic parameters of the weaning weight in beef cattle. Arch Tierz 50, 562-74

Wheeler TL, Cundiff LV, Shackelford SD, Koohmaraie M (2005) Characterization of biological types of cattle (Cycle VII): Carcass, yield, and longissimus palatability traits. J Anim Sci 83, 196-207

Received 9 February 2009, accepted 21 May 2010.

Corresponding author:

LUDĚK BARTOŇ

email: barton.ludek@vuzv.cz

Institute of Animal Science, Přátelství 815, 10401 Prague 10 - Uhříněves, Czech Republic 